\title{
PRINCIPLES THE RULE OF LAW IN THE SETTLEMENT OF THE ELECTION OF HEAD VILLAGE
}

\author{
Fauziyah \\ Faculty of Law, Muhammadiyah University of Jember \\ Jember, Indonesia \\ fauziyah@unmuhjember.ac.id
}

\author{
Sri Praptianingsih \\ Faculty of Law, Muhammadiyah University of Jember \\ Jember , Indonesia \\ Sri_praptianingsih@unmuhjember.ac.id
}

\begin{abstract}
The amount of villages in Indonesia reaches $\mathbf{7 2}$ thousand where the village performs a change of leadership relay in each region. The election of village head is regulated in Act 6 of 2014 where if there is a dispute on the result of Village Head Election is regulated in Article 37 of Act 6 of 2014 stating that the settlement of dispute over election of village head shall be settled by regent within 30 days. Good governance in resolving disputes over village head elections before Law 6 of 2014 is resolved through the judicial system, but after the 6th Act of 2014 has been resolved by district heads in respective district under Law 23 of 2014 on Regional Government, where the dispute resolution of village head election is adjusted With local wisdom (local regulations) that don't conflict with good general principles of government.
\end{abstract}

Keywords---Good Governance, Local Wisdom.

\section{INTRODUCTION}

Good governance is a conception of a clean, democratic and effective governance in the context of civil society formation, with the main idea of governing the relationship between government, business and society. The United Nations Development Program has formulated 9 (nine) characteristics of good governance, one of which is the rule of law principle[1]. This principle mandates that the legal framework should be made fairly and implemented indiscriminately. Related to the implementation of village head elections, especially in the dispute resolution of village head elections, the principle is related to one of the two main foundations of Constitutional Law, namely the principle of state law and democracy [2]. In the principle of a legal state, then one characteristic of all policies and actions must be based on the law.

The mechanism for resolving disputes over village head elections has not been clearly defined either in the Village Law (UU 6/2014) or the implementing law such as Government Regulation No. 43/2014 on the Implementation of Law 6/2014 on Village and

the Minister of Home Affairs Regulation No. 112 / 2014 on Village Head Election.[3] Provisions of Village Law (Law 6/2014) Article 37 paragraphs (6) and (5) stipulates that the Bupati is required to resolve the dispute over the election result of the village head within 30 days, has been followed up by several districts by enacting the Regional Regulations governing the settlement disputes over the election of village heads and those regulations are effective in handling disputes. However, there is no clear provision on the mechanism and form / format of the outcome of the dispute over village head elections[4]. 
Taking into account the number of villages in Indonesia that reach over 70,000 villages and in time will carry out simultaneous village head elections, the existence of dispute resolution mechanisms is clearly necessary. Successful completion of election activities until the inauguration of the village head will determine the smooth running of government services that will ultimately support the smooth service of the government system at the district / city, provincial and national levels. Therefore, the existence of juridical system in handling disputes of village head election which is comprehensive is urgent to be developed soon.

II. Based on the description above, the authors are interested to examine the title of the principle of rule of law in the settlement of disputes village head election PROBLEMS

In order to establish a legal juridical legal system by comparing the model of dispute resolution of village head elections between before Law 6/2014 and after the enactment of Law 6/2014.

\section{III.THEORITICAL REVIEW}

Good Governance In Government Performance

According to G., H., the Addink Principles of Good Governance in power include three functions, legislative, executive, and oversight of power, in which the three are carried out by different agencies.[5]

In line with the opinion of G., H., Addink Ukas[6] says "Good Governance while the legislature, judicial and executive arms of government must be functional and alive to their responsibilities.

Based on the opinion of G., H., Addink above, the nature of regulation and implementation and law enforcement on the settlement of disputes of village head election as a means to protect the constitutional rights as well as the society for the implementation and law enforcement must implement the principles of Good Governance ) as a minimum standard for the government to exercise control over the implementation of local government and village.

In the study of administrative law Concept of Good Governance relates to the activities of the implementation of functions to carry out the public interest[7]. This understanding is in line with his opinion G., H., Addink emphasized the essence of Good Governance is the activity or action (action) of government in the implementation of Public interest. Based on that opinion, the rule of dispute resolution of village head election c. administrative governance is a policy implementation system that implements the public sector efficiently, effectively, decisively, accountably and openly.

The elaboration of the definition of Good Governance with respect to the implementation of 3 (three) government tasks in the economic, political and administrative fields includes[10]:

aims to increase legal certainty and as the fulfillment of constitutional rights and society as a manifestation of Good Governance in Government.

James Gustav states that UNDP defines governance as the exercise of political, economic, and administrative authority in the management of a 
country's affairs at all levels[8]. (governance as the exercise of political, economic and administrative authority in the management of the affairs of a country at all levels). On the basis of this understanding the State Administration Institution (LAN) suggests that the governance understanding has three legs, namely: economic, politic, and administrative which are described as follows:[9] a. economic governance includes a decision-making process that directly or indirectly affects

the economic activity of the country concerned or related to other economies. Because economic governance has influence or implication to equity, powerty, and equality of life. b.political governance refers to the decision making process and the legitimate and

authoritative policy implications

ensure the security of everyone and society (to guarantee the security of all persons and society it self)

b. manage an effective structure for the public sector, the private sector and the community (to manage an effective framework for the public sector, the private sector, and civil society) c. promote economic, social and other objectives in accordance with the will of the people (to pro te economic, social and other aims in accordance with the wishes of the population)

Based on the implementation of good governance (Good Governance), the implementation of Good Governance Principles in the formulation of legislation in the field of dispute resolution of village head election by Bupati related function to organize public interest, that is giving guarantee of law certainty and law enforcement effective and efficient.

\section{IV.RESEARCH METHOD}

Legal research is a process to find the rule of law, legal principle, and legal doctrine to answer the legal issues faced[11].

The research is intended to conducted an assessment of the rule of law principle in resolving disputes of village head election, with the aim to generate new argumentation, concept and legal theory as prescriptions related to the development of village law.

This legal research uses several approaches with the intention of getting information from various legal issues in question to find the answer. The approach used in this study is the statute approach (statute approach), conceptual approach (conseptual approach), and case approach (case approach).

The statutory approach includes two matters, namely the method of legal formation and the method of interpreting the rule of law. The use of the statutory approach is conditio sine quanon for normative law research. According to Peter Mahmud Marzuki the use of the legislation approach not only looks at the form of legislation alone but also examines its content, the study of the ontological basis, the philosophical foundation, and the legis ratio of the provisions of the law [12] This $^{2}$ approach is used to identify and analyze and systematize the various rules of legislation related to the form of state, democracy and Good Governance.

The Conceptual Approach goes from the views and doctrines that develop in the science of law. The concept function in research is to connect 
the world of theory and observation, between abstraction and reality. The concept is defined as the word that states generalized abstractions in special cases, called operational definitions. The importance of an operational definition is to avoid any difference in understanding between the interpretation of a term used. In addition it is also used to provide a handle on the research process.

Using this approach will discuss the concept of state form, democracy in Good Governance with reference to the Principle of legal certainty. The principle of law can be found in the view of scholars or doctrines, laws and judgments[13]. A conceptual approach is used to analyze the concept of dispute resolution of village head elections before and after Law 6/2014.

The method used in the writing of this research is the normative juridical where this writing uses primary legal materials and secondary legal materials. The primary legal material consists of all laws and regulations in Indonesia related to the dispute resolution of village head election, among others; amendment of UUDN RI 1945; law Number 23 of 2014 on Regional Government; Law Number 6 Year 2014 on Village; Government Regulation No. 43 of 2014 jo Government Regulation Number 76 of 2015 on the Implementation of Law Number 6 Year 2014 on Villages; Regulation of the Minister of Home Affairs Number 112 Year 2014 on Village Head Election;

The principal secondary law materials are textbooks containing concepts, basic principles of state law and democracy, basic theories of law and the views of highly qualified graduates[14].
Secondary law materials consisting of journal textbooks, dissertations, professorship inaugural speech, articles, papers and documents related problems in this study

\section{RESULT AND DISCUSSION}

\section{a. Dispute Resolution of Village Head Election before Act 6/2014}

The process of electing the village head, not unlike the election of regional heads, the president and legislators, also gave birth to the winners and the losers in the election. This situation has occurred since the election of the village head was first performed on the earth Republic of Indonesia. In the pre-reform era, however, the news of the losers and the aggrieved party in the election process raised the issue to court. It is very different from postReformation.

The provision of a new constitutional election shall be set forth in the third amendment of the 1945 Constitution in Chapter VII of the General Election, Article 22E number 2, which stipulates: 'Elections shall be held to elect the votes of the DPR, DPRD, President and Vice President and DPRD'. From this provision, it is implied that the election of the village head is not categorized as an election based on the 1945 amendment of the 1945 Constitution.

A democratic party that aims to elect the supreme leader in society. As with the other elections, in this process some are defeated and some are victorious, and not every defeat can be received gracefully.

Not a few candidates and / or supporters who lose the election for various reasons and reasons feel 
aggrieved over the results obtained in the election. Furthermore, it can be guessed that there will be legal issues because of the difference of opinion between the parties who feel aggrieved with the party considered harmful. However, there is no adequate arrangement for the legal efforts of the disadvantaged parties.

The regulation of village head election as set forth in Law Number 5 Year 1979 regarding Village Government (State Gazette of 1979 Number 56, Supplement to State Gazette Number 3153), does not stipulate at all about dispute resolution mechanism in case of dispute concerning process and election results of the village head. Similarly, when the regulation on the village in Law $5 / 1979$ is changed, it becomes part of the implementation of regional government in Law 32/2004 Chapter XI Article 200-216 also not determined dispute resolution mechanism and / or institution authorized to resolve disputes of village head election. Law 32/2004 determines the regulation of village head election set forth in the form of a Regional Regulation, therefore the Regional Government (Regency) has the authority to determine the settlement mechanism and the dispute settlement institution for the village head election.

At the level of regional head election, Law 32/2004 in Article 106 determines that the Court of Appeal and the Supreme Court have the authority to resolve the dispute over the results of the regional head election with a final and binding decision. Having not been placed as part of the electoral activities as stipulated in Law 22/2007 (and later Law 15 2015) on the Implementation of the
General Election, which resulted in the Constitutional Court issued Decision. 97 / PUU-XI / 2013 stipulating that the election of regional head is not included in the general election as referred to in the constitution but is part of the regional government system, therefore the authority of the settlement of disputes is not by the Constitutional Court.

In order to ensure the certainty and smoothness of the local government, especially the election of regional heads, Law 1/2015 on the Stipulation of Government Regulation in Lieu of Law No. 1 of 2014 on the Election of Governors, Regents, and Mayors Became Laws determines that dispute settlement of vote count results the election of regional heads is handled in stages by the High Court and the Supreme Court.

Law of the Republic of Indonesia Number 8 Year 2015 On Amendment To Law Number 1 Year 2015 Concerning Determination of Government Regulation in Lieu of Law Number 1 Year 2014 About Election of Governor, Regent and Mayor Becoming Law to determine dispute over election result of regional head become authority of the Constitutional Court until the formation of the Special Election Tribunal.

\section{b. Dispute Resolution of Village Head Election based on Law 6/2014}

After the village election arrangements were handed over to the local government under Law 32/2004, the legislators again withdrew the authority to regulate the administration of village administrations and the election of village heads into the regulation of the law, in Law of the Republic of Indonesia Number 6 Year 2014 on Villages but surrender the authority to settle the 
dispute on the election result to the Regent / Mayor, as determined by Article 37 paragraph (5) of the regent / mayor, authorizes the elected Head of village as referred to in paragraph (3) to become the Village Head no later than 30 (thirty) days from the date of receipt of the election result (6) In the event of a dispute over election result of the village head, the regent / mayor shall settle the dispute within the period referred to in paragraph (5). Unfortunately, the implementing regulation of Law 6/2014 generally, particularly the resolution of disputes over village head elections, does not further regulate the dispute resolution mechanism. government regulation 43/2014 on the implementing rule of law $6 / 2014$ on villages, government regulation 47/2015 on amendment to Government regulation 43/2014, and ministerial regulation No. 112/2014 on village head Election has not been adequately regulated.

In an effort to follow up the provisions of Law 6/2014 Article 37 paragraph (5) and paragraph (6) as well as to fill the regulatory vacuum, the district / municipal Government takes the initiative to prepare regional regulations concerning the dispute resolution of village head election in each regency / form of Regional Regulation. Some of the local regulations are:

1. regional regulation of Jember regency number 6 year 2006 about village government (Perda Jember 6/2006)

The settlement of disputes over the election of village heads in Jember is contained in Article 59 of Jember regional regulation 6/2006 which states:

(1) Complaints may be made by the village head candidates who feel harmed in the implementation of the village head election to the village Head Election Committee.

(2) Complaints as referred to in paragraph (1) shall be accompanied by complete evidence submitted no later than 1 (one) hour after the counting of votes is declared complete.

(3) The Village Head Election Committee shall immediately take settlement measures within 2 (two) hours after the complaint is received.

(4) The decision of the Village Head Electoral Committee shall be final.

Under this provision, the Election Committee shall have the position of the organizer as well as the court in case of any problems in the vote counting of the election results. As a result, some results of the election committee settlement did not satisfy the troubled parties, who then elected the settlement to the Court. The dispute over village head elections in Jember[15] district is more common than the other two districts (Bondowoso and Lumajang)[16].

2. Regional Regulation of Bondowoso Regency Number 7 Year 2006 Concerning Procedure of Candidate, Election, Appointment and Removal of Village Head (Perda Bondowoso 7/2006)

The settlement arrangement of village head election disputes in Bondowoso is arranged in more detail, although not yet complete. Perda Bondowoso 7/2006 regulates in its own chapter on Dispute for the Implementation of Village Head Election. Article 37 Bondowoso Regulation 7/2006 determines:

(1) In the event of a dispute over the results of the election of the Village Head, the Regent shall establish a Supervisory Team which shall facilitate the settlement of the parties to the dispute. 
(2) The dispute settlement conducted by the Team as referred to in paragraph (1) shall be

consensus and consensus. Furthermore, in

Article 38 determines:

Resolving dispute resolution of village head election as referred to in Article 37 paragraph (1) and paragraph (2) while still in process will not hinder the process of appointment and inauguration of village head and will not affect the decision of village head election result.

According to Article 1 number 26 of the Bondowoso 7/2006 Regulation, the supervisory team is a district level team established by a decree of the regent. The supervisory team is tasked not only to oversee the election process of the village head but also to be a full-time team in resolving disputes outside the judiciary[17].

c. Regional Regulation of Lumajang regency Number 24 Year 2006 Jo.regional regulation of Lumajang regency Number 6 Year 2012 on Amendment to Rule Number 24 Year 2006 About Procedure of Selection, Candidate, Appointment, Inauguration and (Perda Lumajang 24/2006 jo. 6/2012 )

The dispute resolution of village head election is not regulated in Lumajang

Regulation 24/2006 jo.6 / 2012, but regulated in Lumajang Regent Regulation 22/2006 jo.

25/2006. Article 2 paragraph (2) Regulation of regent 22/2006 authorizes the sub-district

head to establish a village election supervisory committee. The "jurisdiction" of this

supervisory committee is the area of sub-district government. While the composition and

membership of the district supervisory committee is regulated in Article 69a paragraph (2) of

Regent Regulation 25/2006, namely:

Chairman: Camat;

Secretary: Secretary of the District
Members: 1. Koramil commander

2. Chief of Sector Police

3. Head of Sub-District Government.

The duties of the supervisory committee under Article 69b of Regent 25/2006 are:

a. To monitor and monitor all stages of active village head elections; b. Receiving reports on complaints about the election of village heads;

c. Complete any complaints of the election of the village head no later than 7 (seven) days after the report of the complaint is received;

d. Continuing unresolved complaints to the Village Administration Implementation Team of the Regency at the latest 7 (seven) days after the complaint is received;

e. Submit reports to the Bupati on the implementation of monitoring and monitoring of village head elections.

Thus the sub-district supervisory committee conducts both

repressive oversight. Preventive monitoring aims to prevent the occurrence of disputes, conducted with the socialization and briefing of BPD, Village Election Committee and the

Village about the importance of maintaining commitment to the implementation of every stage of village head election takes place properly, correctly, honestly and fairly in the

district.

In the case of one or more things the kecamatan supervisory committee can not resolve the dispute over the election of the village head within 7 (seven) days after the

complaint is received, the committee delegates the settlement to the Problem Solving Team

of the Village Government with the jurisdiction of the district. The team is appointed by the

Bupati, with the arrangement and membership:

Responsible Person: Administrative Assistant;

Chairman: Head of Village Government Section; 
Secretary: Head of Sub Division of Village

Government;

Members: 1. Head of Local Government Work Unit;

\section{Head of National Unity and Politics} Board;

3. Head of the Civil Service Unit;

4. Head of Legal Affairs;

5. Head of Governmental Section;

6. Elements of Village Governance.

Ironically, the duties and authorities, work procedures and others in order to solve

the dispute over the election of village heads by the Settlement Team on the Problem of

Implementing the Village Government are not regulated either the Lumajang Regional

Regulation 24/2006 jo.6 / 2012, and the Regent Regulation of Lumajang 22/2006 jo .

25/2006.

From the results of the research, the workings of the Problem Solving Team of

Village Governance in Lumajang was unique. If the dispute over village head elections can

not be resolved by the Village Head Election Supervisory Committee (sub-district level) and then delegated to the Problem Solving Team of Village Government (district level), the Team

immediately goes to the village concerned and seeks to the maximum extent possible for the dispute to be settled and on that day[18]. By looking at the working mechanism of the Problem Solving Team of Village Governance, it appears that sociological approaches are used instead of the juridical approach to resolving disputes over village head elections. This success may be related to the commitment of the Lumajang district government to organize village head elections well, correctly, honestly and fairly while maintaining public order and security, even more Team membership all comes from government elements.
The results of this study indicate that basically the district government is well aware that it is possible that there will be a dispute in the series and / or after the election of the village head, hence the regulation and / or regulation governing it should be made, which arrangement is not found in the above legislation.

\section{d. CONCLUSION}

The principle of the rule of law in the dispute resolution of village head election before Law 6/2014 through the court institution (litigation), this happened in Jember district, while in Lumajang and Bondowoso regencies by non litigation. Then the settlement of the dispute over the village head election post Law 6/2014 was resolved by the Bupati / Walikota. Implementation of Permendagri No. 112 of 2014 that the Pilkades disputes concerning the "election process" are solved independently by the Electoral Committee, where the nature of the selection of the final election committee is final and binding. While the dispute over the election of the village head concerning the counting of the vote results is resolved by the regent / mayor within 30 (thirty) days from the proposal of ratification received by the regent

/ mayor. The Village Law does not govern how the jurisdiction of the courts to test or resolve disputes concerning processes and outcomes. This is in contrast to the legislative election law and the regional head election law which provides legal means for disputes beyond the vote to be resolved through the Administrative Court (PTUN), while the dispute over the vote is resolved by the 
Constitutional Court (MK), resulting in a clear and

\section{REFERENCES}

[1] G. H. Addink in Philiphus M. Hadjon "Human Rights in the Prespective of Administrative Law", a paper presented at the National Workshop on Empowerment of Legal Culture in the Protection of Human Rights in Indonesia organized by the Doctoral Program of Law Science UNDIP, Semarang on 21 June 2004

[2] Ibid , h.33

[3] Government Regulation No. 43/2014 on implementing regulations of Law No. 6/2014 and Ministerial Regulation No. $112 / 2014$ on the election of village heads.

[4] Fauziyah and Sri Praptianingsih, Pattern of dispute resolution Pilkades in Bondowoso, Journal Rechtsidee, FH University of Muhammadiyah Sidoarjo January-June 2015 h.11-20

[5] G. H. Addink, Staats en Bestuurrecht, Principles of Good Governance Part (1), Utrecht, Universitiet, 2010, h. 114

[6] Ukase, P. (2011) "The Legislature, Good Governance and Democratic Sustenance in Benue State. Vol. 10, No. 1 \& 2. h. 78

[7] Philiphus M. Hadjon, Hukum administrasi sebagai Instrumen Hukum Untuk Mewujudkan Good Governance, Dalam Buku Hukum Administrasi dan Good Governance, Universitas Trisaksakti, 2010, h. 9

[8] James Gustave, Goverment For Sustainable Human development, United Nations Development Programme, 2000, h. 2

[9] Ibid definite legal dispute resolution system .

[10] Philipus M. Hadjon, Op Cit, h. 67 Lihat G. H. Addink, Reader, Principles of Good Governance, Facultiet Rechtsgeleerdheid Universitiet Utrecht, Collegejaar, 2009/2010, h. 13

[11] Check Peter Mahmud Marzuki, Legal Research, Revised Edition, Kencana Prenada Media Group, Jakarta, 2013, p. 61. Also check Philiphus M. Hadjon and Tatiek Sri Djatmiati, writing legal research methods or in wide scope as an examination of law, should be derived from the legal nature of the law Philipus M. Hadjon Tatiek Sri Djatmiati Arguments Legal legal steps Problem solving and penyususnan Legal Opinion, Gajah Mada University Press, Yogyakarta, 2005, p. 3.

[12] Ibid

[13] bid, hal. 177-180

[14] Peter Mahmud Marzuki, Op. Cit., hal. 20

[15] Amira Paripurna and Pramukhtiko, identification of village head dispute resolution in Jember district, Fairness and Justice Journal, Vol. 1 No. 8, May, 2010

[16] Fauziyah and Sri Praptianingsih, Settlement Pattern of village head election disputes in Lumajang District, Rechtsidee Journal Faculty of Law University of Muhammadiyah Sidoarjo July-december, 2016.

[17] Fauziyah dan Sri Praptianingsih, 2015, "Settlement Pattern of village head election disputes in Bondowoso District Rechtsidee Journal Faculty of Law University of Muhammadiyah Sidoarjo, January-June 2015.

[18] Ibid. 